\title{
Evaluation and Management of the Physicochemical Variables of Asu River, Southeast, Nigeria
}

\author{
Nwinyimagu Amaechi Joshua ${ }^{1}$, Nwonumara Godwin Nkwuda ${ }^{2}$, Ani Chijioke ${ }^{2} \&$ Ukeje Ikechukwu Ogeze $^{3}$ \\ ${ }^{1}$ Forestry Department, Ministry of Environment, Ebonyi State, Nigeria \\ ${ }^{2}$ Department of Biological Sciences, Ebonyi State University, Abakaliki, Ebonyi State, Nigeria \\ ${ }^{3}$ Federal University of Ndufu-Alike Ikwo, Ebonyi State Nigeria, Nigeria \\ Correspondence: Nwinyimagu Amaechi Joshua, Forestry Department, Ministry of Environment, Ebonyi State, \\ Nigeria. E-mail: amaechijn@gmail.com
}

Received: October 28, 2015 Accepted: January 8, 2016 Online Published: March 10, 2016

doi:10.5539/jsd.v9n2p54 URL: http://dx.doi.org/10.5539/jsd.v9n2p54

\begin{abstract}
Asu River is one of the major tributaries of Cross River, a tropical reforest river in southeast Nigeria. The climate of the region is divided into the wet and dry seasons. Human activities such as fishing, bathing and washing go on in the river especially during the dry season. Farming also takes place at the fringes of the river. Some important physicochemical parameters of the river were investigated at two designated sites comprising the downstream and the upstream for nine (9) months, from October, 2013 to June, 2014. Temperature, carbon (iv) oxide, conductivity, total dissolved solids, nitrate and phosphate recorded maximum values during the dry season while dissolved oxygen and $\mathrm{pH}$ recorded maximum values in the wet season. The physicochemical variables evaluated showed that the river is not in a critical condition as most of the variables recorded are within the WHO permissible limit. However, the paper therefore recommends the need for public enlightenment on environmental management and control of household and industrial wastes in order to sustain the usefulness of Asu River.
\end{abstract}

Keywords: physicochemical variables, freshwater, ecosystem, water quality, Asu River, Ebonyi State

\section{Introduction}

Rivers as freshwater ecosystems are believed to be very much pivotal in shaping and sustaining the economy of nations throughout history. It is useful to man as sources of drinking water, fisheries, as means of transportation, production of hydroelectricity, irrigation, industrial and domestic water supplies and in waste water disposal (Small \& Cohen, 1999). The use of water especially rivers in particular in sewage disposal and as dump site for industrial effluents greatly affect water qualities. In sustainable management approach of any aquatic ecosystem, evaluation of its physiochemical characteristics is very important. This is because it determines the reproductive success of fish and other aquatic organisms (Moses, 1983) in the aquatic ecosystem. Rivers and other freshwater bodies collect precipitation from the surrounding landscape and channel same through their interconnected networks and wetlands that recharge them. Therefore, they can respond quickly to even distant anthropogenic activities (Combes, 2003). To achieve a long-term protection of freshwater species, the implicit physical processes of freshwater system that are most vulnerable to change must be identified. Also necessary is determining how changes in these physical features can impact the resident biological organisms (Combes, 2003). The major sources of pollutants to rivers comprise water from market stall and flushing of sewage. Others are water arising from slaughter houses, surface runoff from farmlands and water draining from street washing (Ademoroti, 1996). There is therefore, need for public enlightenment on use of chemical fertilizers on farms near and around rivers and on control of household and industrial wastes so as not to pollute this case Asu River.

The aim of this study is to evaluate the physiochemical characteristics of Asu River, Southeast Nigeria during October, 2013 to June, 2014 and harness the usefulness of the information derived in the study in sustainable management of the river and other similar rivers. According to Moses (1983), the evaluation of the physiochemical characteristics of water is very important in determining the distribution and production of fish and other aquatic lives. Therefore, this study tries to capture some knowledge on the water quality of Asu River knowing that there is still poor state of knowledge on it. 


\section{Materials and Methods}

2.1 Study Site

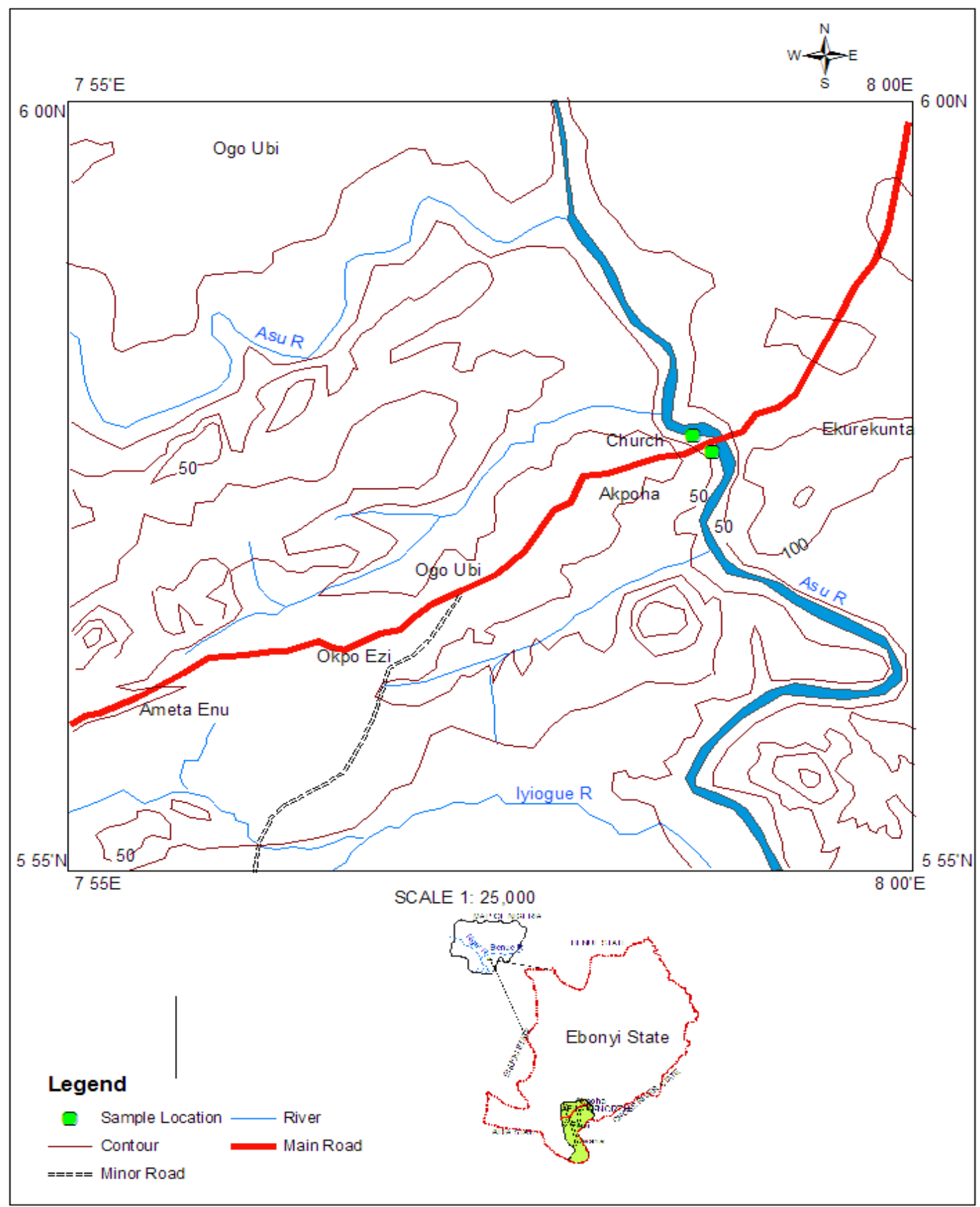

Figure 1. Map of Akpoha showing Asu River

The study was carried out within the stretches of Asu River, Southeast, Nigeria. Asu River lies between longitude $7.55^{\circ} \mathrm{E}$ and $8.00^{\circ} \mathrm{E}$ and latitude $5.56^{\circ} \mathrm{N}$ and $6.00^{\circ} \mathrm{N}$. It is connected to the Atlantic Ocean through the Cross River with a confluence at about $7 \mathrm{~km}$ from Akpoha Bridge. Asu River is however, located in the South Eastern Nigeria where there is relatively high annual rainfall. The climate of the region is typically tropical with two distinct 
seasons: the wet and dry seasons. The wet season starts in May and last till October, while the dry season sets in from November through April. This though, may vary from year to year consequent upon change in climate and the resultant change in hydrological regime.

During this study two sampling sites were mapped out and investigated: a downstream and an upstream. Site 1 is the downstream located immediately behind the bridge across the river. It is partially shaded by trees forming a canopy over it. The substratum of a section of site 1 is muddy with sediments of decaying leave litters and was covered with stones towards the middle of the river. It was usually the landing point for the fishermen. Some human activities there include bathing, laundry and mini car wash. Site 2 is about $2 \mathrm{~km}$ upstream of site 1 . Major parts of the substratum have fewer decaying plant matter but the bank area was very sandy. Sand dredging is the major activities in site 2 .

\subsection{Water Analysis}

Samples for water analysis were collected from the two designated sites for a period of nine (9) months starting from October, 2013 to June, 2014. Temperature, Dissolved oxygen (DO), total dissolved solids (TDS), pH and Conductivity were measured insitu using portable Hanna field meters. Carbon (iv) oxide was determined using titration method (Ekubo and Abowei, 2011). Nitrate and Phosphate were both determined according to AOAC (2003). However, ammonium ion concentration was determined according to Solórzano (1969), modified for a 10 $\mathrm{ml}$ sample volume.

\section{Results and Discussion}

\subsection{Water Temperature}

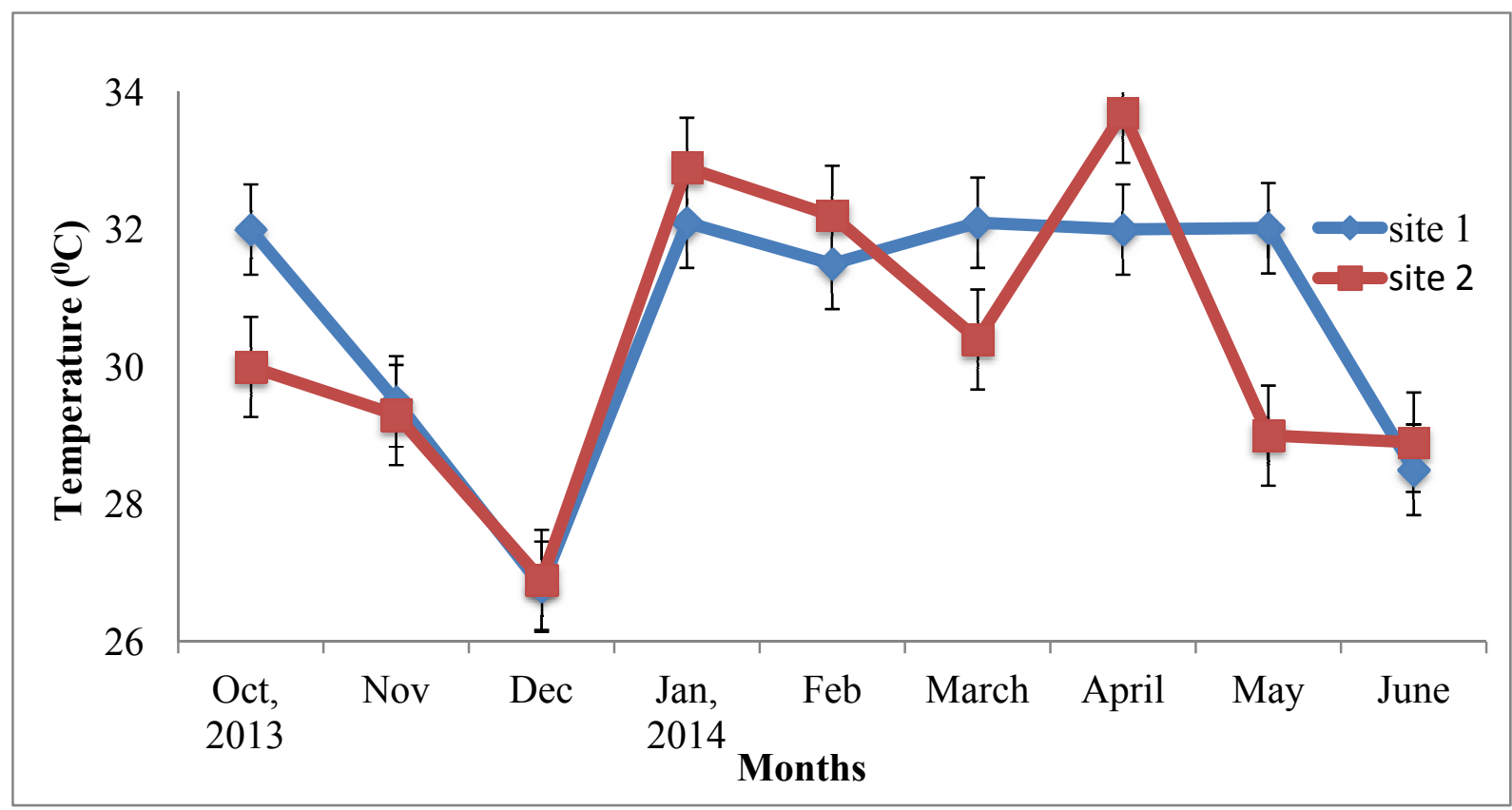

Figure 2. Monthly variation in water temperature in Asu River

Temperature is being controlled by the amount of light penetrating through the water strata. It plays very significant role in the development, growth and reproduction of organisms in both terrestrial and aquatic ecosystem (Ekubo and Abowei, 2011). Temperature affects physical, chemical and biological processes in water bodies and can also influence water conductivity. During this study, temperature varied between $26.8^{\circ} \mathrm{C}$ and 33.7 ${ }^{0} \mathrm{C}$ with minimum temperature recorded in December at site 2 and maximum recorded in April at site 1 (Fig. 2). This variation in temperature between the wet and dry seasons might be as a result of seasonal changes in the meteorological variables in the tropics (Aoyagui and Bonecker, 2004), usually associated with reduced atmospheric humidity, little or no rainfall in the dry season. Ekubo and Abowei (2011) stated that continuous increased in water temperature due to evaporation could inhibit the phytoplankton growth and thereby, affect the aquatic food-chain. 


\subsection{Dissolved Oxygen (DO)}

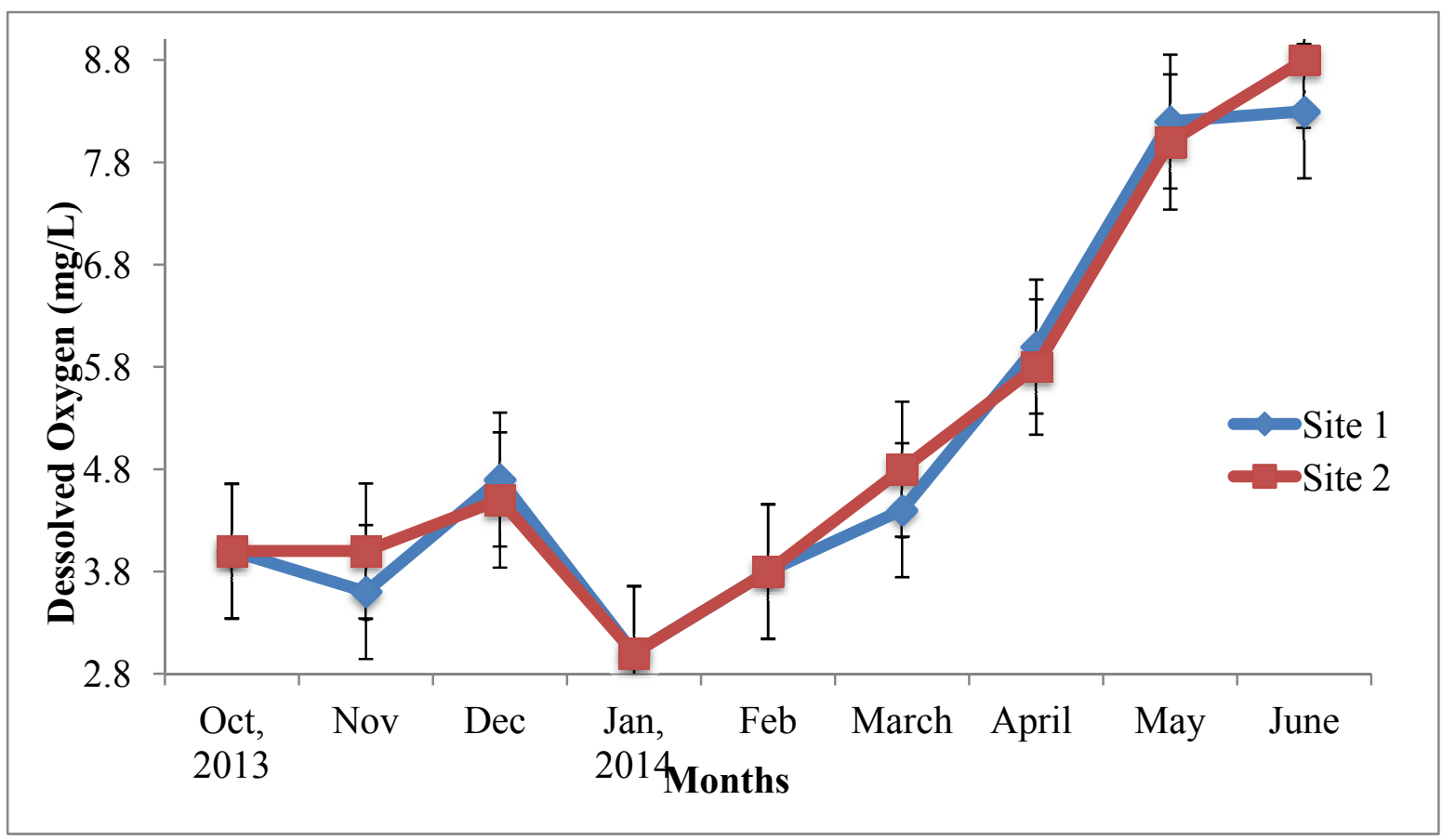

Figure 3. monthly variation in dissolved oxygen in Asu River

The primary source of dissolved oxygen in water is by direct absorption at the air-water interface. DO is also a by-product of biological activities in aquatic ecosystem. The amount of dissolved oxygen in water is very important for aquatic organisms as its concentration in water has effects on the growth and survival, distribution, behavior and composition of the organisms (Solis, 1988). For instance, low concentration of dissolved oxygen creates anoxic condition which is the major causes of faunal death and low density in the aquatic ecosystem (Saiz-Salinas, 1997). During this study, DO concentration in Asu River recorded minimum value $(3.0 \mathrm{mg} / \mathrm{L}) \mathrm{in}$ January at site 1 and maximum value $(8.7 \mathrm{mg} / \mathrm{L})$ in June at site 2 (Fig. 3). The increase in the level of dissolved oxygen during the rainy season can be linked to increase in water velocity and a more turbulent flow (Gautam etal., 1993) which is very common with tropical rivers. This condition ensures proper mixing at air-water interface. Furthermore, respiration by phytoplankton, riparian vegetations and submerged plants (Savikumar \& Karuppasamy, 2004) could also contribute to the increase in dissolved oxygen. Kutty (1987) and Abowei (2010) both suggested that decrease in DO concentration in the dry season is probably due to increase in water temperature which affects oxygen solubility in water.The low DO recorded in the dry season may also be attributed to increasing human interferences at the fringes of the river as Asu River reduces in volume greatly to enhance human access in the dry season. It may also probably be due to shading by macrophytes. Shading by surface floating macrophytes can reduce photosynthesis and consequently, dissolved oxygen availability (Pennak, 1971). 


\subsection{Total Dissolved Solids (TDS)}

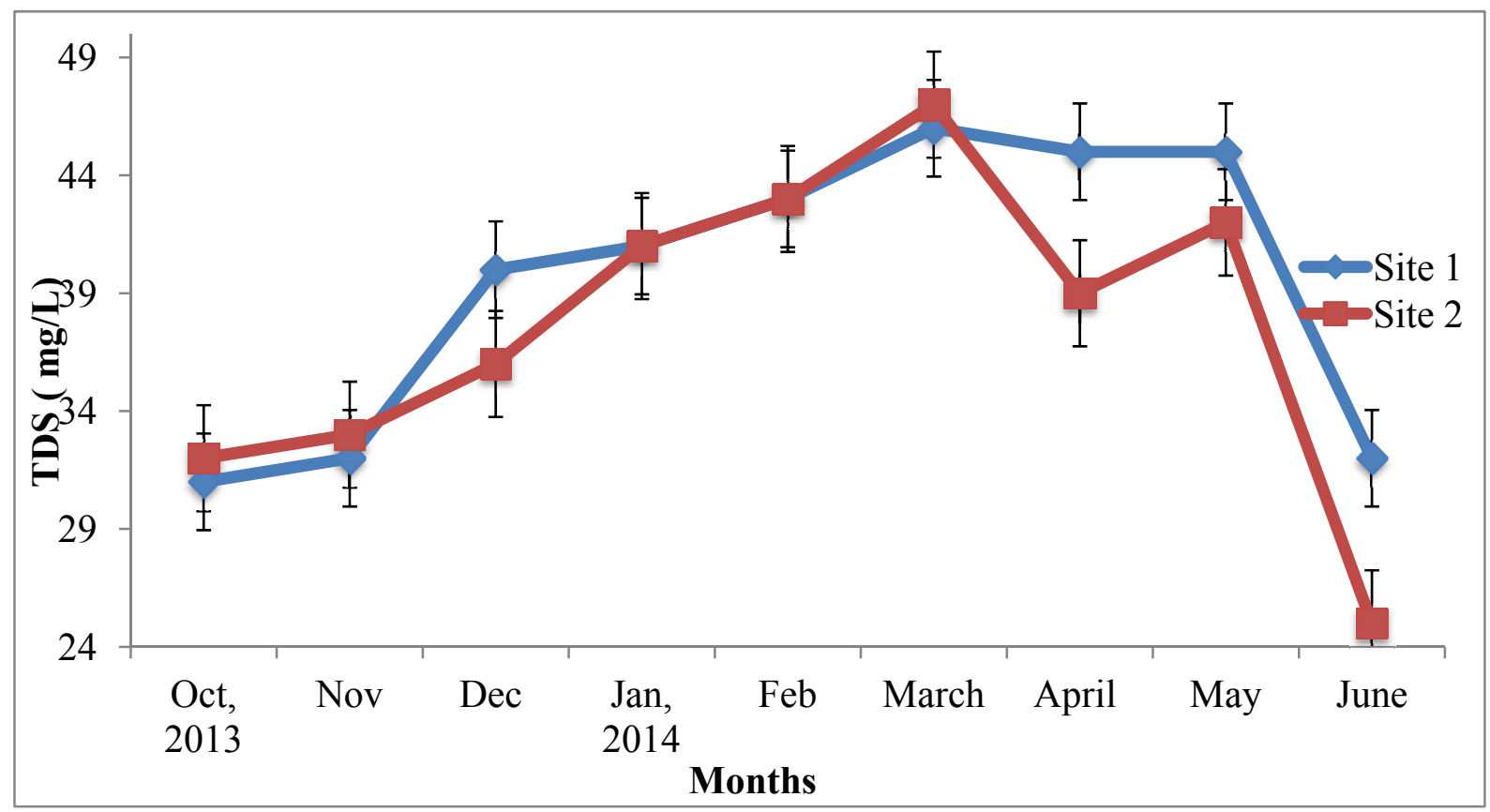

Figure 4. Monthly variation in total dissolved solids in Asu River

Total dissolved solids refer to the amount of dissolved minerals in any water body. It is a measure of water suitability for both domestic and industrial uses. In Asu River during this study, total dissolved solids (TDS) recorded a monthly variation that ranged between $25 \mathrm{mg} / \mathrm{L}$ and $47 \mathrm{mg} / \mathrm{L}$ with minimum and maximum values recorded in June at site 2 and in March at site 2, respectively (Fig. 4). High values of total dissolved solids (TDS) observed during the dry season could be attributed to decrease in water volume due to high evaporation. MacIntyre and Melack (1984), Setaro and Melack (1984) and Hamilton and Lewis (1987), opined that elevated atmospheric temperature and low humidity could reduce water volume; a condition that can greatly increase the salt concentration of rivers. These observations have made it clear that TDS tends to increase in the dry season. The challenge therefore, is the management practices to adopt so as to sustain Asu River and other similar rivers in the dry season. Such practices should look into ways of either increasing the water level in the dry season to counter the TDS concentration or reduce the amount of solids entering the water during the wet season. However, preserving the habitat connectivity can never be ruled out in conservation strategies of Asu River ecosystem. Connectivity is important so much in freshwater ecosystems as it can preserve hydrological regimes, promote ecological balance, and ensure successful migration of animals between different habitats at various life history stages. Abell etal. (2002) suggested that connectivity is significantly important along the length of rivers, and between freshwater habitats and subterranean systems or groundwater sources. 


\subsection{Water $\mathrm{pH}$}

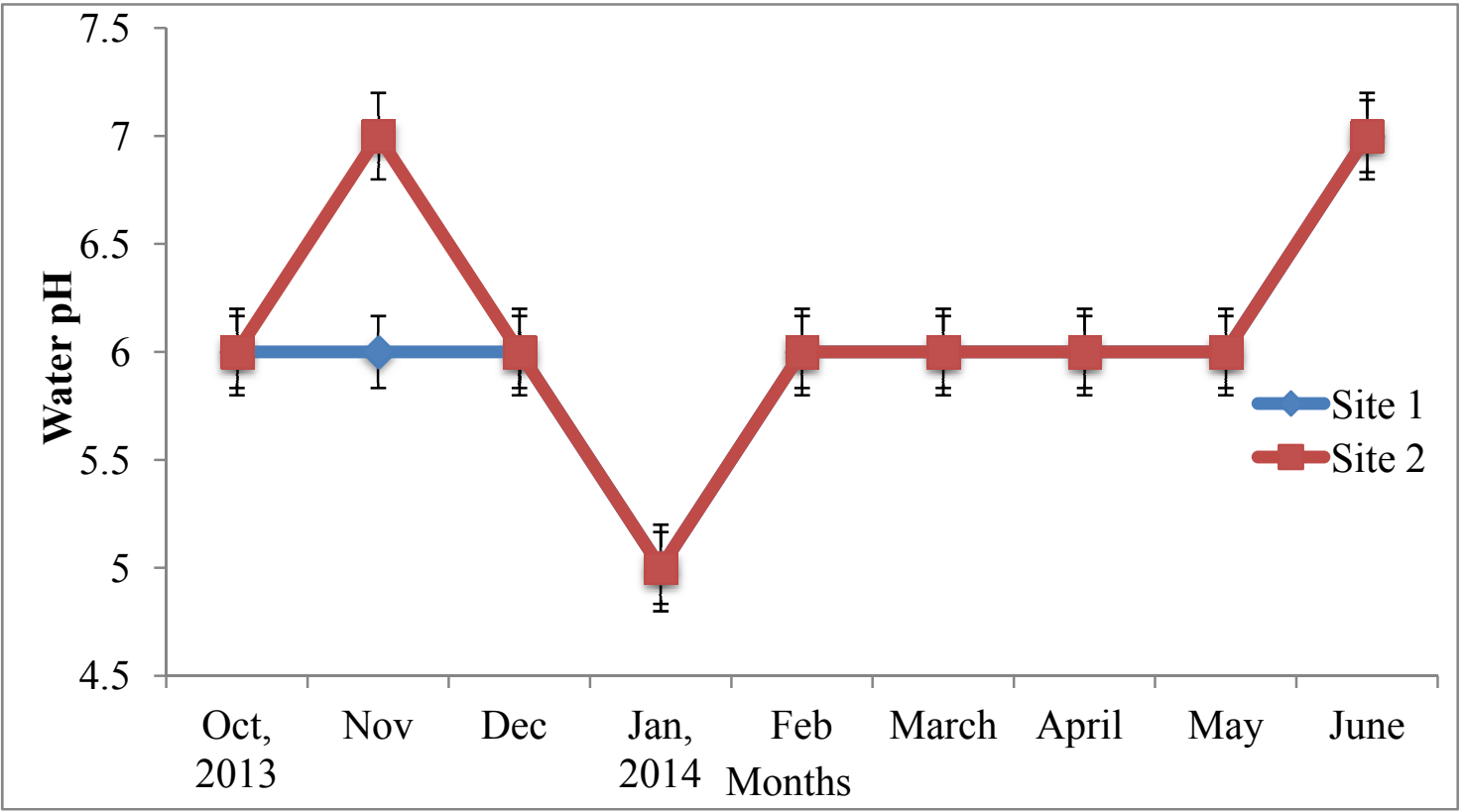

Figure 5. Monthly variation in $\mathrm{pH}$ in Asu River

$\mathrm{pH}$ is the measure of hydrogen ion concentration. The level of hydrogen ion concentration $(\mathrm{pH})$ in water is very vital. The $\mathrm{pH}$ value of any water body is inversely proportional to the amount of Carbon (iv) oxide and directly proportional to the amount of dissolved oxygen. Water with more dissolved oxygen tends to be more basic than water with more $\mathrm{CO}_{2}$ concentration. Abowei (2010), reported that, an ideal $\mathrm{pH}$ for biological productivity rages from 7 to 8.5 whereas, a $\mathrm{pH}$ lower than 4 is harmful to aquatic organisms. It was observed that water $\mathrm{pH}$ in Asu River ranged from 5 to 7 (Fig. 5) during the study. The minimum and maximum values were observed in the dry and rainy seasons, respectively. The decrease in water $\mathrm{pH}$ of the river during the dry season was as a result of increase in the concentration of carbon (iv) oxide which is an acidic gas, owing to the possible decrease in photosynthetic activities of phytoplankton during the period as suggested by Boyd (1979) and Wani and Subla (1990) in their respective studies. 


\subsection{Conductivity}

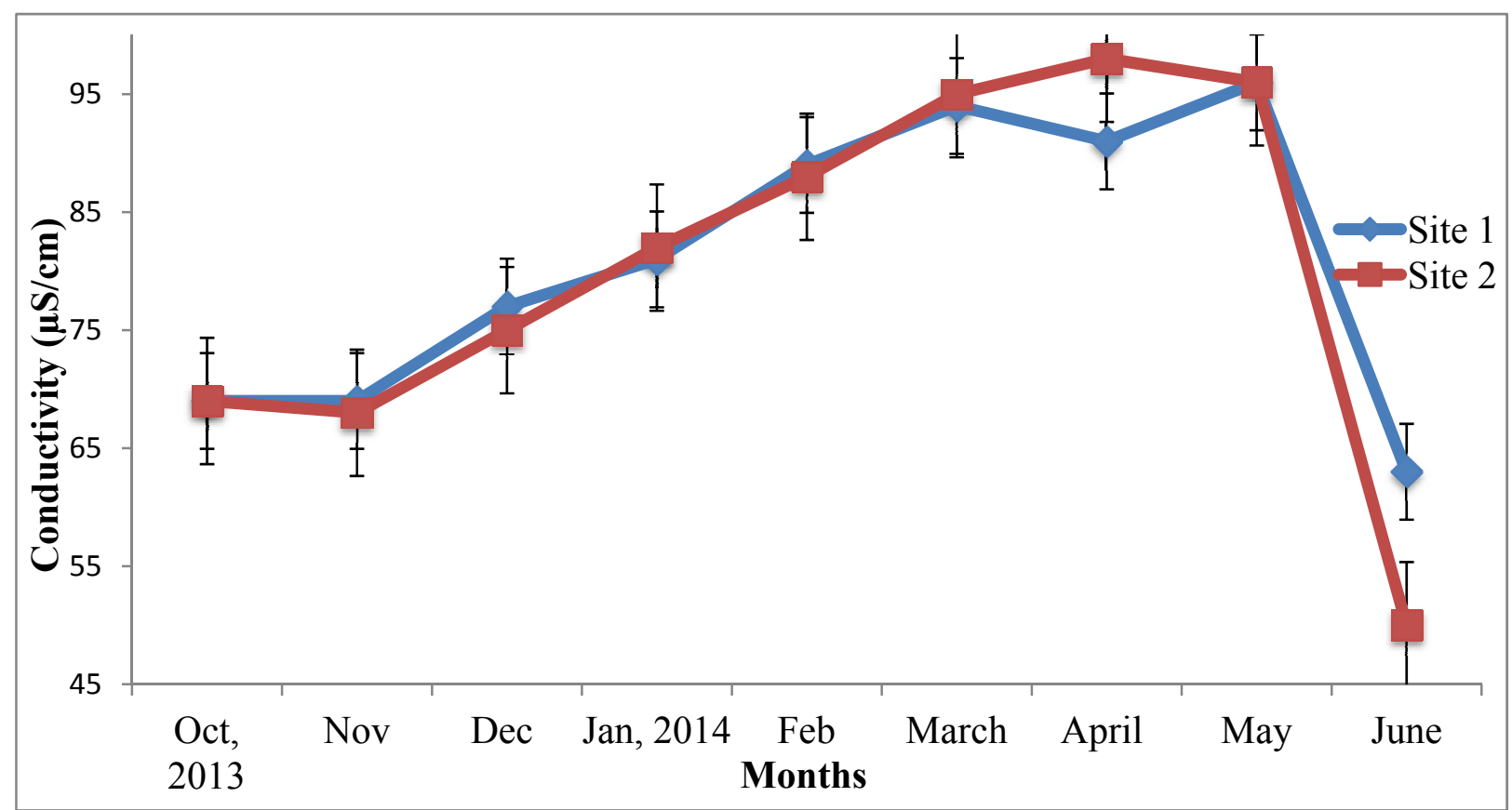

Figure 6. Monthly variation in conductivity in Asu River

Conductivity is the measure of the ability of water to conduct an electrical current. This depends on the ionic concentration and temperature of the water body. Abowei (2010) reported that, there is a direct proportionate relationship between conductivity and total dissolved solids in water. As more dissolved solids are added, water conductivity increases in the other hand. However, the optimum conductivity for various aquatic organisms differs from one organism to another and from species to species. During the study, conductivity was lower in the wet season with minimum recorded in June $(50 \mu \mathrm{S} / \mathrm{cm})$ at site 1 and maximum in April $(98 \mu \mathrm{S} / \mathrm{cm})$ also at site 1 (Fig. 6).High values of conductivity in dry season could be attributed to decrease in water volume due to high evaporation, resulting from increased atmospheric temperature and low humidity (MacIntyre \& Melack, 1984; Hamilton \& Lewis, 1987; Setaro \& Melack, 1984). 


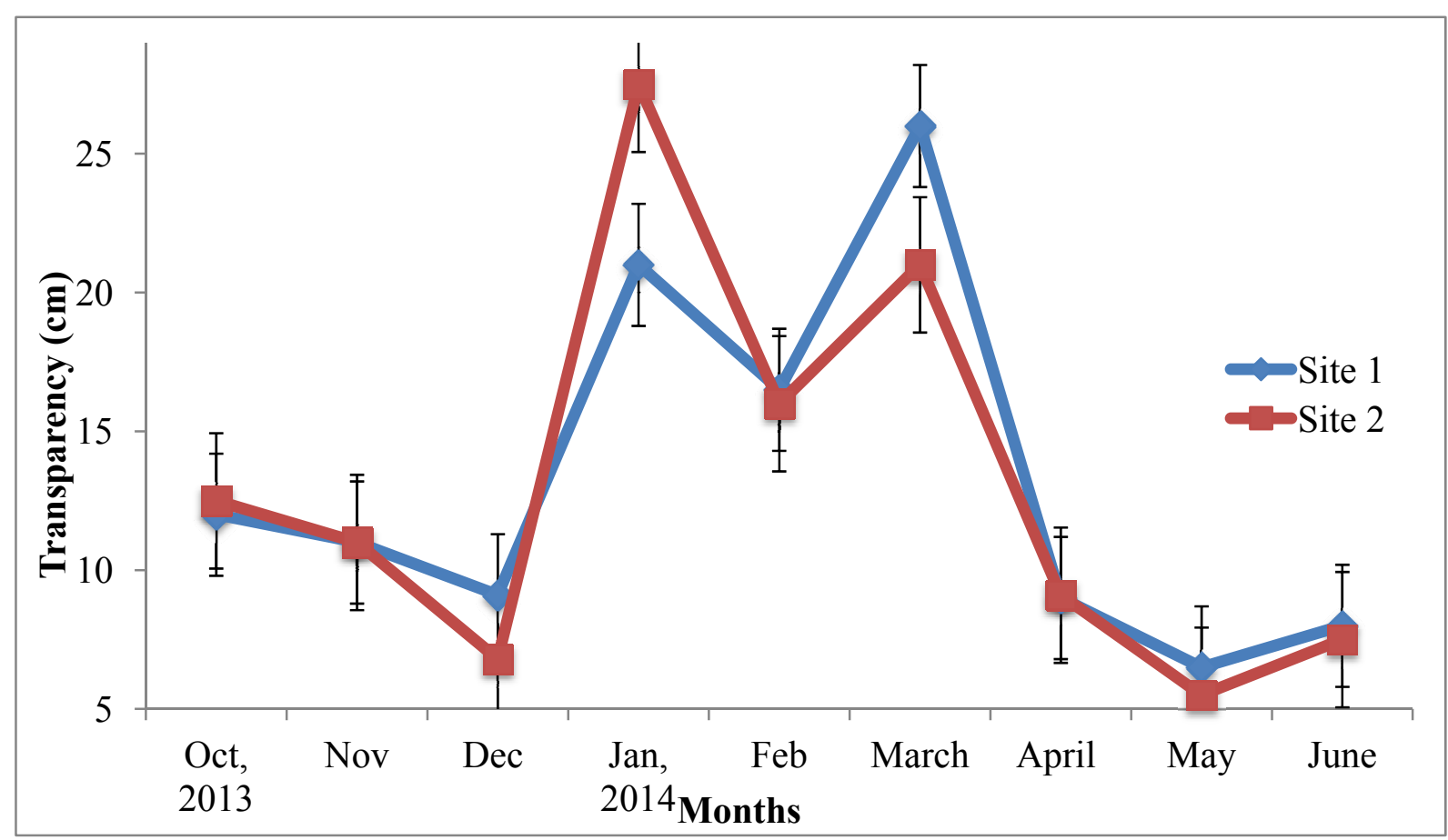

Figure 7. Monthly variation in transparency in Asu River

Transparency is referred to as the tendency of water to transmit light. The ability of water to transmit light is probably its most important attribute. Without it, photosynthesis would not take place and, as a result, no life could exist in water (Ekubo and Abowei, 2011). Water transparency is a product of the amount of dissolved solids contained or suspended on water. Heavy presence of plankton can also reduce water transparency (Ramachandra and Solanki, 2007). The study showed a monthly variation in transparency with minimum value $(6.8 \mathrm{~cm})$ recorded in site 1 in December and maximum recorded in January $(27.5 \mathrm{~cm})$ at site 2 (Fig. 7). The low value of transparency record during this study in the wet season was as a result of rainfall and flooding which affected the dept and limit of the photic zone by reducing light penetration down the water column. Colloidal organic matter originating from the decay of vegetations and erosion of soil resulting from surface runoff could be responsible for decrease in transparency during the wet season (Nigatu, 2010). 


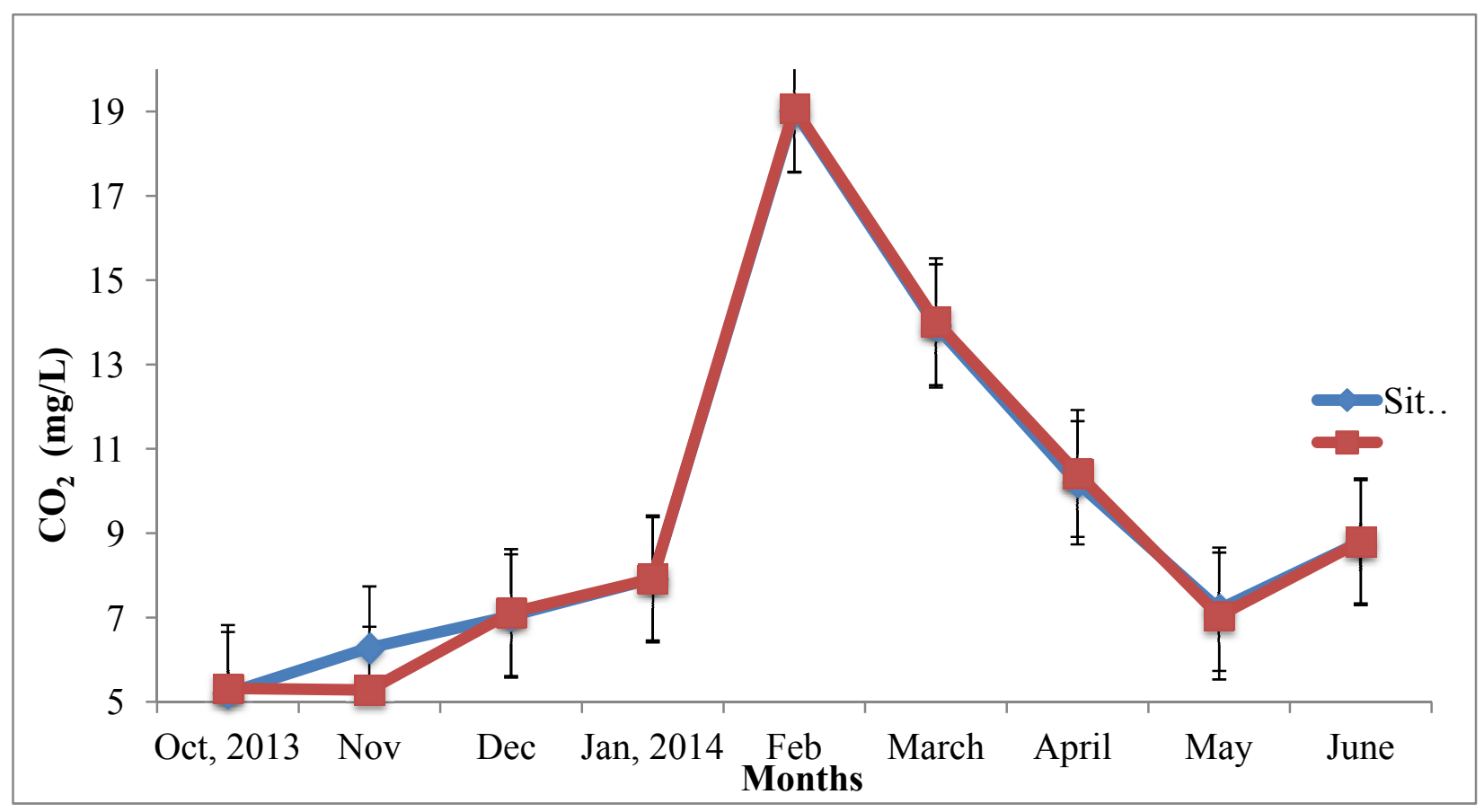

Figure 8. Monthly variation in carbon (iv) oxide in Asu River

Carbon (IV) Oxide is a weak dibasic acid, which ionizes slightly. It is a byproduct of respiration and source of carbon fixation in photosynthesis. Increase in natural free $\mathrm{CO}_{2}$ results in the decrease of dissolved oxygen in natural waters (Ekubo and Abowei, 2011). $\mathrm{CO}_{2}$ may occur in water inform of bicarbonate or in the dissolved bound form as carbonate, depending on the $\mathrm{pH}$ of the water. Water is classified as soft, medium or hard, depending on the amount of bound $\mathrm{CO}_{2}$. When the bound $\mathrm{CO}_{2}$ is less than $5 \mathrm{mg} / \mathrm{L}\left(25 \mathrm{mg}\right.$ of $\left.\mathrm{CaCO}_{3}\right)$, the water is soft. But, when the bound $\mathrm{CO}_{2}$ is $5-22 \mathrm{mg} / \mathrm{L}\left(100 \mathrm{mg}\right.$ of $\left.\mathrm{CaCo}_{2}\right)$, it is medium. The water is described as hard when the bound $\mathrm{CO}_{2}$ is above $22 \mathrm{mg} / \mathrm{L}$ (Ekubo and Abowei, 2011). In this study, monthly variation in $\mathrm{CO}_{2}$ concentration in Asu River was between $5.32 \mathrm{mg} / \mathrm{L}$ in October at site 1 and $19.08 \mathrm{mg} / \mathrm{L}$ in February at site 2. The minimum and maximum were recorded in wet and dry seasons respectively. Decrease in the concentration of carbon (iv) oxide in the wet season may be due to its depletion, possibly as a result of increased phytoplankton abundance and decreased decomposition and respiration as suggested by Wani and Subla (1990). The result indicates that Asu River can however be classified as not being soft nor had based on the amount of bound $\mathrm{CO}_{2}$ as its concentration was within 5-22mg/L (Fig. 8). 


\subsection{Nitrate $\left(\mathrm{NO}_{3}\right)$}

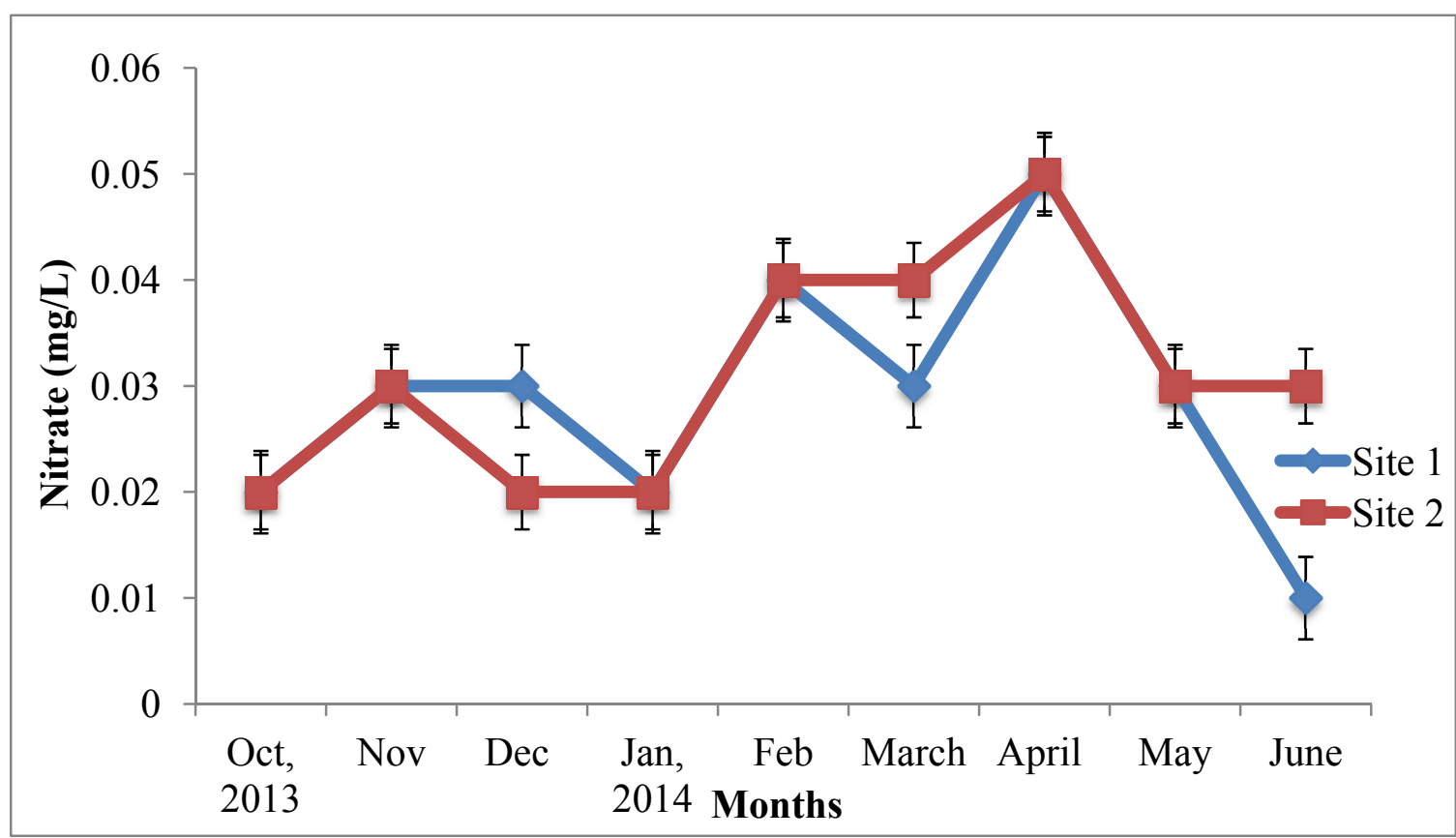

Figure 9. Monthly variation in nitrate in Asu River

Nitrate is an oxidized form of nitrogen. It is essential in protein synthesis. Nitrogen concentration of any water body speaks a lot about the nutrient content of the water body hence, its enhancement support heavy growth of phytoplankton. The primary source of nitrogen in water bodies is agriculture (Alfoldi, 1983), through surface runoff. The study in Asu River showed that nitrogen concentration in the river ranged between $0.01 \mathrm{mg} / \mathrm{L}$ and 0.05 $\mathrm{mg} / \mathrm{L}$. Minimum nitrate concentration was observed in the month of June at site 1 while maximum was record in April at both site 1 and 2 (Fig. 9). Nigatu (2010) made similar observations and attributed increase in nitrate concentration to runoff from farm lands, slaughter houses, residential and industrial sewages. Decomposition of nitrogenous organic matter can also increase nitrate concentration in rivers.

\subsection{Phosphate $\left(\mathrm{PO}_{4}\right)$}

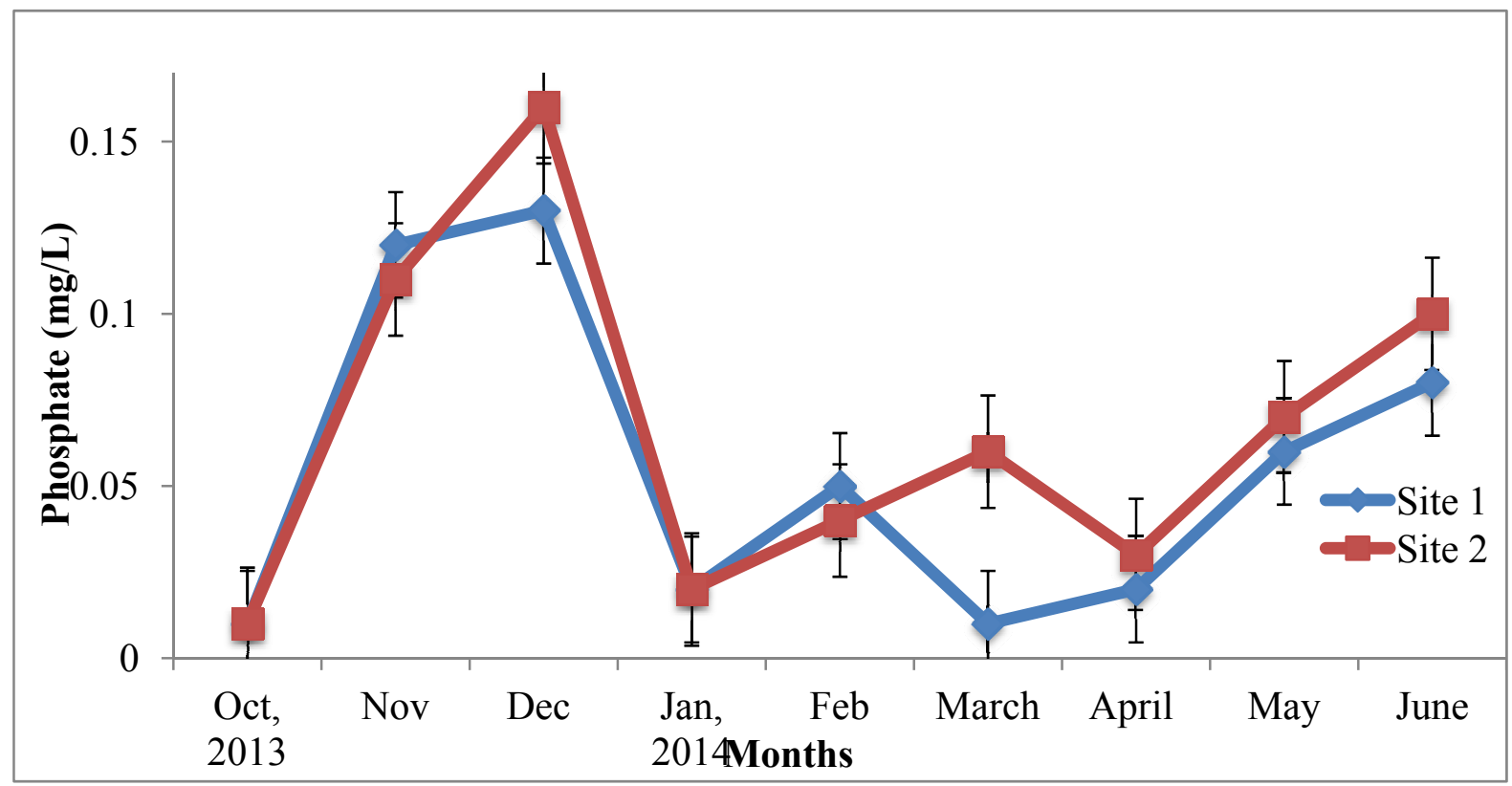

Figure 10. Monthly variation in phosphate in Asu River 
Phosphate is a primary nutrient for algae. Its enhancement in rivers can cause algal bloom. This is the reason it is being classified as water pollutant. However, initiative to reduce loads of phosphorus to water is a key to reducing phytoplankton biomass. During this study, the concentration of phosphate in Asu River varied from $0.02 \mathrm{mg} / \mathrm{l}$ to $0.16 \mathrm{mg} / \mathrm{L}$. The value of phosphate was highest in December at site 2 and lowest in January at both site 1 and 2 and also in April at site 1 (Fig. 10).Nigatu (2010) recorded similar values and suggested that the increase in phosphate concentration in the water can be attributed to increase in the use of chemical fertilizers, use of detergents, waste water from laundering agents, run-off from farm lands, slaughter houses, residential and industrial sewages.

\subsection{Ammonium ion $\left(\mathrm{NH}_{4}^{+}\right)$}

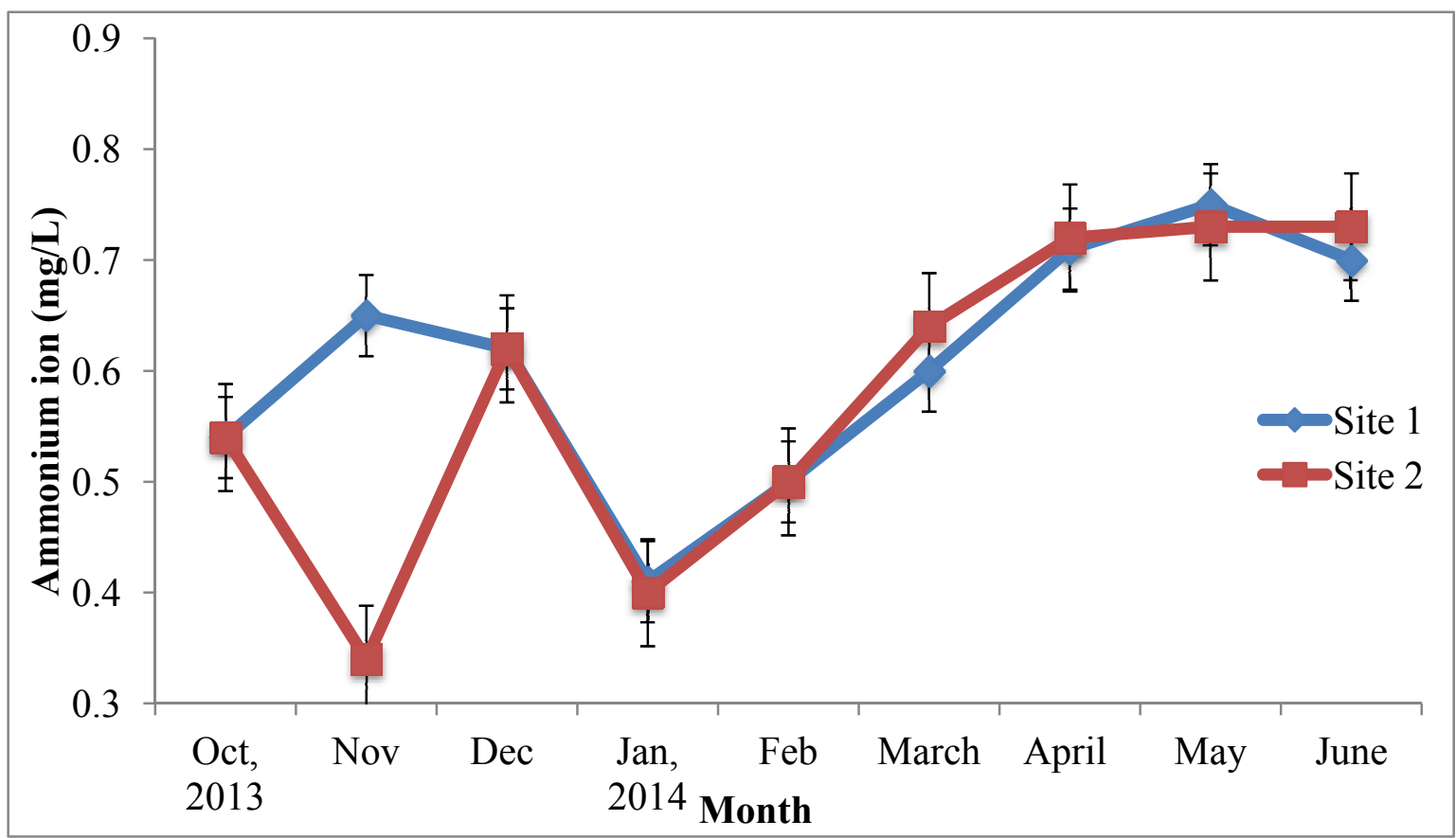

Figure 11. Monthly variation in ammonium ion in Asu River

In an aquatic ecosystem, ammonium ion is usually a product of nitrification. Although, natural sources are responsible for most of its occurrences in water, anthropogenic activities have added greatly to increase in its concentration. In the present study, it fluctuated between $0.34 \mathrm{mg} / \mathrm{L}$ and $0.75 \mathrm{mg} / \mathrm{L}$ across the wet and dry seasons. It however, recorded minimum value at site 2 in November and maximum value at site 2 in May (Fig. 11). The reduction in the concentration of ammonium ion in Asu Riverduring thedry season may be as a result of its sequential conversion by two groups of nitrifying bacteria to nitrogen (iv) oxide ion and trioxonitrate (v) ion (Ekubo and Abowei, 2011) respectively, which is readily available for uptake by aquatic plants.

\section{Conclusion}

Freshwater ecosystems respond conspicuously to physical variables such as water temperature, depth, flow rate, and discharge rate as well, to variability in these factors. Rivers are therefore, expected to show response to global climate change in line with the variability in the physiochemical parameters and how they relate to the species composition, abundance, diversity and biomass of both the macro and micro organisms especially the plankton community. The study on the physicochemical variable of Asu River showed that there were spatial and temporal variations among the variables evaluated. The extent to which the variability observed can impact the ecosystem should be a concern for further researches. However, the river is not under serious threat of pollution going by the World Health Organization (WHO) permissibility checklist.

\section{Acknowledgements}

We express our sincere gratitude to the Department of Biological Sciences, Ebonyi State University, Abakaliki, for providing necessary facilities, Assoc. Proff. O. I. Okogwu, Mr. C. Uhuo and C. N Mgbebu who guided us during the analysis of water samples for physicochemical variables. And also, to Mr. Ibrahim Inya, a fisherman 
who conducted us round the river during the sampling period.

\section{References}

Abell, R., Thieme, M., Dinerstein, E., \& Olson, D. (2002).A source book for conducting Biological Assessment and Developing Biodiversity Vision for Ecoregion conservation(Volume 11: Freshwater Ecoregions). World Wildlife Fund, Washington D.C; USA. 201pp.

Abowei, J. F. N. (2010). Salinity, Dissolved Oxygen, pH and Surface Water Temperature Conditions in Nkoro River, Niger Delta, Nigeria. Advanced Journal of Food Science and Technology, 2(1): 16-21.

Ademoroti, L. M. A. (1996).Environmental Chemistry and Toxicology. Foluelex Press Ltd, Ibadan.

Alfoldi, L. (1983). Movement and Interaction of Nitrates and Pesticides in the Vegetation Cover-Soil Groundwater-Rock System. Environmental Geology, 5, 19-25. http://dx.doi.org/10.1007/BF02381296

AOAC International. (2003).Official methods of analysis of AOAC International (17th ed., 2nd revision). Gaithersburg, MD, Association of Analytical Communities.

Aoyagui, A. S. M., \& Bonnecker, C. C. (2004). Rotifers in different environments of the upper Parana River floodplain (Brazil): richness, abundance and the relationship to connectivity. Hydrobiologia, 522, 281-290. http://dx.doi.org/10.1023/B:HYDR.0000029980.49859.40

Boyd, C. B. (1979). Water Quality in Warm Water fish Ponds. Auburn University, Agricultural Experiment. Station. Auburn.

Combs, S. A. (2003). Protecting Freshwater Ecosystem in the Face of Global Climate Change. In L. J.Hoffman (Ed.), Buying Time: A User's Manual for Building Resistance to Climate Change in Natural Systems (pp. 177-216).

Ekubo, A. A., \& Abowei, J. F. N. (2011). Review of some Water Quality Management Principles in Culture Fisheries. Research Journal of Applied Science, Engineering and Technology, 3(12), 1342-1357.

Gauntam, A., Joshi, V. P., \& Sati, O. P. (1993). Physicochemical characteristics of sewage and its impact on water quality of Alkananda at Strinagar (Garhwal). Journal of Ecotoxicology and Environmental Monitoring, 3, 61-63.

Hamilton, S. K., \&Lewis, W. M. Jnr. (1987). Chemistry and nutrient mass balance of a lake on the Orinoco River, Venezuela. Limnology and Oceanography, 23, 245-267.

Kutty, M. N. (1987). Influence of ambient oxygen on the swimming performance of goldfish and rainbow trout. Canadian Journal of Zoology, 46, 647-653. http://dx.doi.org/10.1139/z68-091

MacIntyre, S., \& Melack, J. M. (1984). Vertical mixing in Amazon floodplain lakes.Verhandlungen des Internationalen Verein Limnologie, 22, 1283-1287.

Moses, B. S. (1983). Introduction to tropical Fisheries. Ibadan University Press, UNESCO/ICSU, Part, pp. $102-105$.

Nigatu,E. (2010). Water Quality and Phytoplankton Dynamics in Geffersa Reservoir, Ethopia. A thesis Presented to the School of Graduate Studies In Partial fulfillment of the requirements for degree of Master of Science in Biology, 66p.

Pennak, R. W. (1971). Towards a classification of lotic habitats. Hydrobiologia, 38, 321-334. http://dx.doi.org/10.1007/BF00036842

Ramachandra, T. V., \& Solanki, M. (2007). Ecological Assessment of Lentic Water Bodies of Bangalore. Envis Technical Report: 25. Indian Institute of Science, Bangalore.

Saiz-Salinas, J. I. (1997). Evaluation of Adverse Biological effects induced by Pollution on the Bilbao Estuary (Spain). Environmental Pollution, 3, 357-359. http://dx.doi.org/10.1016/s0269-7491(97)00042-0

Setaro, F. V., \& Melack, J. M. (1984). Responses of phytoplankton to experimental nutrient enrichment in an Amazon floodplain lake. Limnology and Oceanography, 29, 972-984. http://dx.doi.org/10.4319/lo.1984.29.5.0972

Small, C., \& Cohen, J. E. (1999). Continental Physiography.Climate and the Global Distribution of Human Population, 965-971.

Solis, N. B. (1988).The Biology and Culture of Penaeus Monodon, Department papers. SEAF DEC Aquaculture Department, Tigboun, Biology, Philippines. 3-36. 
Solórzano, L. (1969). Determination of ammonium in natural waters by the phenolhypochlorite method. Limnology and Oceanography, 14, 799-801. http://dx.doi.org/10.4319/lo.1969.14.5.0799

Wani, I. A., \& Subla, B. A. (1990). Physicochemical features of two shallow Himalayan Lakes. Bulletin of Environmental Science, 8, 33-49.

World Health Organization. (1993).Guidelines for drinking waterquality. In E.Wilson (Ed.), Reservoirs Brian-Henderson shellers (pp. 210-222). WHO Geneva.

\section{Copyrights}

Copyright for this articleis retained by the author(s), with first publication rights granted to the journal.

This is an open-access article distributed under the terms and conditions of the CreativeCommons Attribution license (http://creativecommons.org/licenses/by/3.0/). 